\title{
JBPML: crescendo com as investigações na área da Patologia
}

O Jornal Brasileiro de Patologia e Medicina Laboratorial (JBPML) está se tornando cada vez mais o veículo nacional de informações científicas de uma grande parcela daqueles que estão, de alguma forma, envolvidos em estudos ou trabalhos acadêmicos e profissionais na área da Patologia neste país. Está completando um ano que o JBPML passou a receber e editorar os manuscritos por via eletrônica. Há também um ano iniciamos uma campanha entre patologistas brasileiros e outros pesquisadores e profissionais de áreas relacionadas com a anatomia patológica para redigirem seus resultados de pesquisa e observações consideradas de interesse e enviá-los ao JBPML para análise visando a sua publicação. Essa campanha não foi muito ruidosa, mas foi veiculada pelos principais instrumentos de comunicação da Sociedade Brasileira de Patologia (SBP).

O afluxo de manuscritos para determinada revista científica é essencial para sua consolidação, pois permite selecionar os trabalhos submetidos, com certa margem de liberdade, pelo mérito científico. A carência de demanda por espaços para publicação é um dos problemas atuais de muitas revistas científicas brasileiras da área médica, que tentam sobreviver e adquirir credibilidade em uma competição desigual com enorme quantidade de periódicos científicos estrangeiros, já bem acreditados cientificamente (conforme exposto no editorial do JBPML, v. 45, n. 6, 2009). Coincidentemente ou não, após o início da campanha da SBP por artigos científicos para o JBPML, passamos a receber um número crescente de submissões, ultrapassando com folga aquela perigosa margem mínima (submissões versus espaço disponível) necessária para um equilibrado trabalho de seleção. Tem sido elevada quantidade desses artigos, não somente remetidos por patologistas da área médica, mas também de outras áreas correlatas, como a odontológica e a de ciências básicas e de pesquisa experimental. Essas últimas geralmente vinculadas a cursos de pós-graduação, que necessitam cada vez mais de espaço para a comunicação de seus crescentes resultados de pesquisa.

Uma vez que o leque de matéria publicável do JBPML é bastante amplo, o aporte permanente de informações científicas de qualidade das diferentes áreas da Patologia e da Medicina Laboratorial torna-se o primeiro passo na trajetória da revista, visando seu crescimento e aperfeiçoamento constantes. Nesse sentido, reiteramos o convite a todos os profissionais e estudiosos das áreas cobertas por este periódico para continuarem enviando suas informações científicas e produtos de seus estudos.

Como é de se esperar, o aumento de submissões de manuscritos corre em paralelo à maior demanda de trabalho de análise editorial. Felizmente, o JBPML tem contado com a permanente colaboração de revisores, que têm atendido prontamente às solicitações da comissão editorial para esta, vamos dizer, delicada atividade de julgamento crítico dos manuscritos. Sem esse trabalho voluntário de numerosos colegas, o qual consome precioso tempo, a espinha dorsal da revista estaria fatalmente comprometida.

Finalmente, vale lembrar que o JBPML é publicado bimestralmente, tem uma tiragem bruta de 3.600 exemplares, é indexado na Litereatura Latino-Americana e do Caribe em Ciências da Saúde (LILACS), na Periódica e no Chemical Abstracts e é integrante da base de dados SciELO. Sua política editorial é promover a comunicação de trabalhos científicos das áreas de Medicina Laboratorial (Patologia Clínica), Patologia (Anatomia Patológica) e Citopatologia. 